\title{
SEPULCHRAL RELIEF FROM ATTICA, AT WINTON CASTLE, HADDINGTONSHIRE.
}

THE Attic sepulchral relief reproduced on Plate $B$, is the principal object in an interesting collection of antiques formed by the late Baroness Ruthven of Winton Castle, Haddingtonshire, and assigned by her to the Museum of the Society of Antiquaries of Scotland. The bulk of the collection, consisting of vases, mostly of a small size and of the black figured kind, but including several good Attic lekuthoi, is now deposited in the Museum, but the most notable objects remain still at Winton Castle. These comprise a fine hydria $13 \frac{1}{2}$ inches high, with a red-figured design (Paris, Helen and other figures with Erotes, etc.) very delicately drawn in the best style, and two sepulchral reliefs, of which one is small and of poor workmanship, and the other, now for the first time published, an interesting and charming work.

It is a stele of Pentelic marble rounded at the top, $61 \frac{1}{2}$ inches in height $17 \frac{1}{3}$ wide at base, and about an inch less above under the architrave. On the face, upon an unmoulded plinth between pilasters which bear upon simple capitals a shallow architrave and cornice, stands in profile to the left the figure of a girl $41 \frac{1}{2}$ inches high, whose name, APIETOMAXH, appears inscribed on the architrave. Above the cornice is an anthemion ornament in relief of the usual design. The weight of the figure is on the right foot, the left knee being bent, and the right hand holds a small draped figure in a sitting posture-apparently a terracotta idol. The dress is a thin chiton, over which is an ample himation enveloping the figure and covering the left arm and hand. The head is slightly bent to look at the small figure, and the hair, bound with a fillet, falls down over the back of the 
neck. The style and workmanship suit the fourth century B.C., with which date agrees the simple elegance of the forms of the anthemion ornament.

The characteristics of the Attic sepulchral relief are well represented here. There is undeniable style in the work, and much refinement and grace of expression in the figure, but at the same time there is in parts a curious neglect in the workmanship. The type of the head and the winning sweetness of the girlish features are fully representative of the best qualities of this interesting phase of Greek sculpture. The rendering of the folds of the himation is without elaboration and the forms are sharplyangled and square, but the work is that of a bold carver who knew his business well. In remarkable contrast is the neglect of the left hand under the robe, which the sculptor has not been at any pains to indicate, so that the effect is that of an arm cut off at the wrist. The hair is roughly worked, the feet somewhat clumsy. The hand holding the figure is, on the contrary, nicely felt. The relief is in the highest part about two inches from the ground; the back of the stele roughly chiselled.

The chief facts about the discovery of the relief, as far as they can now he ascertained, are as follows. Shortly before the breaking out of the Greek Revolution in 1821, Lord and Lady Ruthven spent a year in Athens, and acquired the use of some land containing ancient burial places near Cape Zoster, a few miles from the city. Here the relief of Aristomache was discovered a few feet below the surface of the ground, and with the rest of the proceeds of the excavations it was sent home to Scotland to be placed in the hall at Winton Castle. The wooden case, with the corners filled in with packing of Attic moss, still incloses the relief which was consigned to it in the Peiraeus more than sixty years ago, and the red earth in which the marble was embedded still adheres to the surface. The freshness of aspect thus retained by the work is one of its titles to interest, and in connection with this it is to be observed that though the surface is innocent of the washing and scouring which the marbles in so many collections have undergone, no traces of polychromy are to be observed on it. Not less fresh and redolent of Greece was to the last the memory of its accomplished owner. Lady Ruthven, whose years numbered nearly a hundred, remembered well the days of her 'grand tour' and her stay in Athens. She H.S.-VOL. VI. 
knew Ali Pasha who interested himself in her search for antiques, and was acquainted with Byron's 'Maid of Athens' though the poet himself she did not meet. An excellent artist in water colours in the bold and masculine style of 'Grecian' Williams, Lady Ruthven executed some valuable drawings of the ancient buildings of Athens in their then condition, and she still loved to talk about the beautiful scenes of Greece whither-with the enthusiasm of youth still unquenched-she would fain again have turned her feet. It gave her the liveliest satisfaction that the Hellenic Society desired to publish the charming relief which had been one of the delights of her life.

G. Baldwin Brown. 